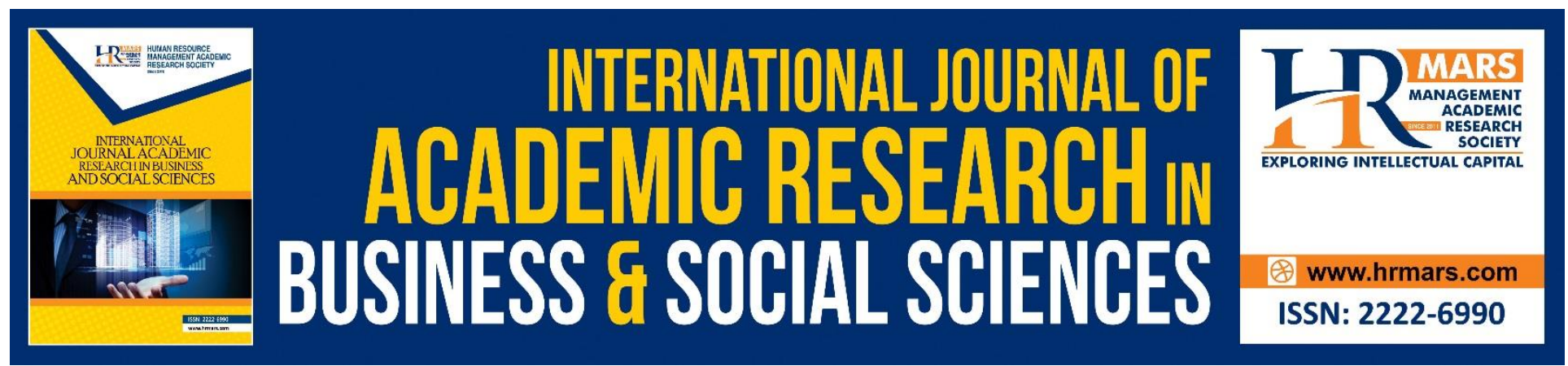

\title{
Board Characteristics and Firm Performance: Malaysia's Government-Linked Companies (GLCS) Compliance to Green Book
}

Noraisyah Abd Rahman and Mohd Waliuddin Mohd Razali

To Link this Article: http://dx.doi.org/10.6007/IJARBSS/v9-i1/5387

DOI: $\quad 10.6007 /$ IJARBSS/v9-i1/5387

Received: 28 Dec 2018, Revised: 13 Jan 2019, Accepted: 26 Jan 2019

Published Online: 30 Jan 2019

In-Text Citation: (Rahman \& Razali, 2019)

To Cite this Article: Rahman, N. A., \& Razali, M. W. M. (2019). Board Characteristics and Firm Performance: Malaysia's Government-Linked Companies (GLCS) Compliance to Green Book. International Journal of Academic Research in Business and Social Sciences, 9(1), 174-190.

Copyright: (C) 2019 The Author(s)

Published by Human Resource Management Academic Research Society (www.hrmars.com)

This article is published under the Creative Commons Attribution (CC BY 4.0) license. Anyone may reproduce, distribute, translate and create derivative works of this article (for both commercial and non-commercial purposes), subject to full attribution to the original publication and authors. The full terms of this license may be seen

at: http://creativecommons.org/licences/by/4.0/legalcode

Vol. 9, No. 1, 2019, Pg. 174 - 190

http://hrmars.com/index.php/pages/detail/IJARBSS

JOURNAL HOMEPAGE

Full Terms \& Conditions of access and use can be found at http://hrmars.com/index.php/pages/detail/publication-ethics 


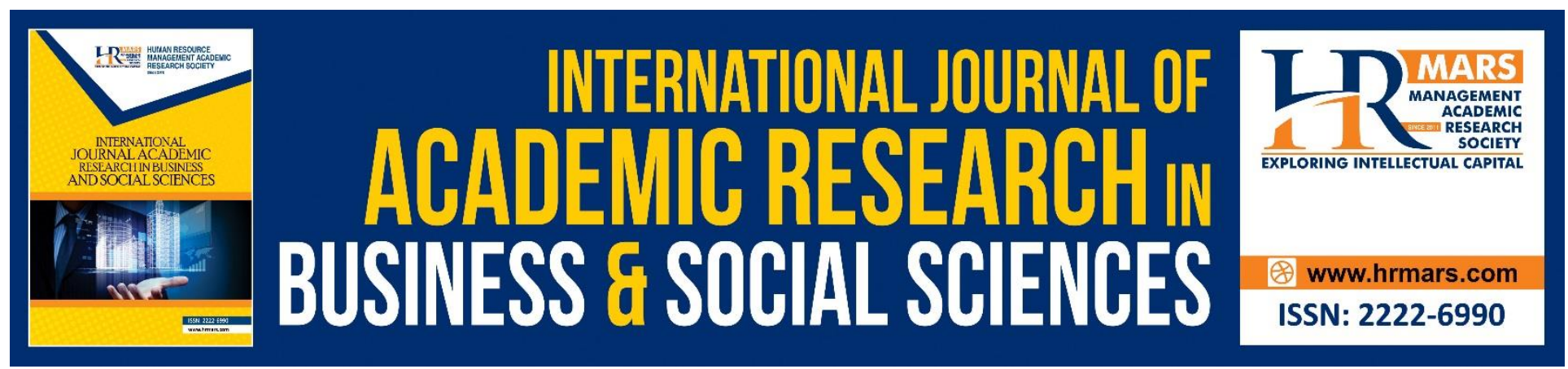

\title{
Board Characteristics and Firm Performance: Malaysia's Government-Linked Companies (GLCS) Compliance to Green Book
}

\author{
Noraisyah Abd Rahman ${ }^{1}$ and Mohd Waliuddin Mohd Razali ${ }^{2 \& 3}$ \\ ${ }^{1}$ Faculty of Management and Economics, Universiti Pendidikan Sultan Idris (UPSI) \\ ${ }^{2}$ Faculty Economics and Business, Universiti Malaysia Sarawak (UNIMAS) \\ ${ }^{3}$ Faculty of Economics and Management, Universiti Kebangsaan Malaysia (UKM) \\ Email: noraisyahabdrahman@yahoo.com ${ }^{1}$
}

\section{ABSTRACT}

The Government-Linked Companies Transformation (GLCT) Programme was introduced in 2005 as the Malaysia Government efforts to improve the performance of government-linked companies (GLCs) under its control. One of the main policy thrusts in this framework is the need to upgrade the effectiveness of GLCs boards which led to the launching of the Green Book on April 2006. Focusing on the Green Book structuring high-performing board guidelines, this study tries to examine whether compliance to its recommended board characteristics of size, independence and remuneration has any effect on GLCs performance. Thus, GLCs financial performance for three years before (2004, 2005 and 2006) and three years after $(2007,2008$ and 2009) the guidelines became mandatory effective on 1 January 2007 are analyzed and compared. The results show that the Green Book is a successful tool to increase board effectiveness in its monitoring function. However, compliance to board characteristics of size, independence and remuneration do not affect GLCs performance. Thus, it can be concluded that the influence of the Green Book as corporate governance factor is insufficient to explain the variations in GLCs performance.

Keywords: Green Book, Board Characteristics, Firm Performance, Government-Linked Companies Transformation

\section{INTRODUCTION}

The Malaysia GLCs play a major role in helping to develop the economy of the country. However, due to the impact of 1997/1998 Asian Financial Crisis, the GLCs performance had been weak over the years (Ministry of Finance, 2007). Malaysian Government reacted to this by introducing a ten-year plan known as the Government Linked Company Transformation (GLCT) Program in year 2005. This program is supported by Ten Initiatives represented by ten different 
coloured books. Each book has its own specific objective towards a betterment of a specific area in the GLCs.

Focusing on the heart of corporate governance which is the board, the Green Book was launched on April 2006 as one of the effort called by the Malaysian Government to enhance board effectiveness. The Green Book high-performing board guidelines serve to strengthen the board with its mandatory compliance. This study focuses on observing the effect of compliance to the recommended board characteristics under the Green Book policy guidelines on GLCs performance.

Weak board is a phenomenon not only to underperforming GLCs but also to better performing GLCs. According to a review ${ }^{1}$ on the governance of GLCs boards, it is found that even for better-performing board, there revealed several weaknesses include insufficient individual and collective board performance accountability, insufficient time spent to address critical issues like strategy, talent review and risk management, too much focus on 'letter' rather than 'spirit' of rules and procedures resulting in inconsistent board processes such as board meeting logistics and focus.

The Government implemented the GLCT program and issued the Green Book in April 2006 to address weak board problem among the GLCs. The Book provides a framework to identify specific areas for improvement in order to strengthen the GLCs boards and recommends practical potential solutions, that once adopted could raise the overall level of board effectiveness. These include compliance to policy guidelines on structuring high-performance board.

Since the issuance of the Green Book in 2006, little has been said about the effect of compliance to the guidelines on GLCs performance. With the reported loss by Sime Darby Bhd, there is an issue raised that the policy guidelines of the Green Book does not achieve its aim to strengthen the GLCs boards and may lead to the failure of GLCT program which due to complete in year 2015. However this claim has not yet been proved and becomes a motivation for this research study.

\section{Objectives of Study}

There are several objectives of this study as follow:-

1. to determine whether there is any significant difference in GLCs performance before and after issuance of the Green Book.

2. to investigate whether the Green Book is an effective additional instrument to strengthen GLCs boards by comparing GLCs performance with non-GLCs performance before and after issuance of the Green Book.

3. to examine whether board characteristics (size, independence and remuneration) has any significant relationship to GLCs performance before and after) issuance of the Green Book.

a) to determine whether GLCs with low proportion (33.33\% to $49.99 \%$ ) and high proportion ( $50 \%$ and above) of independent directors would perform significantly different to each other before and after issuance of the Green Book.

${ }^{1}$ See; http://www.pcg.gov.my Section 20, III. 


\section{LITERATURE REVIEW}

\section{The Government Linked Companies (GLCs)}

The $\mathrm{GLCs}^{2}$ are corporate entities that have a primary commercial objective in which the Government has direct controlling stake. Having this controlling stake, the Government directly or through government linked investment companies (GLICs) ${ }^{3}$ is able to appoint the board of directors, senior management or make major decisions on contract awards, strategy, restructuring and financing, acquisitions and divestments for the GLCs. GLICs primary role is to allocate government funds to the GLCs and seen to be the investment arms of the Government. The participations of $33 \mathrm{GLCs}^{4}$ in various industries including automobile, airlines, telecommunication, power, technology, property and transportation are recognized and significant in developing our nation's economy. Statistics by Ministry of Treasury ${ }^{5}$ shows that GLCs accounted for 23 out of 100 companies listed in Kuala Lumpur Composite Index (KLCI) but represented $55 \%$ of the index's market capitalization. The expenditure of listed GLCs on fixed capital investment amounted to approximately RM13.8 billion representing $18 \%$ of national Gross Fixed Capital Formation in 2006. The large amount of capital investment by GLCs relative to other companies is due to high capital intensity ratios. GLCs remain the main providers of utility and infrastructure services and are capable to provide acceptable returns to the shareholders. Besides that, GLCs have employed 325,722 personnel or about $3 \%$ of the national workforce in 2006.

Empirical study by Ab Razak, Ahmad,and Aliahmed (2008) who examined the impact of an alternative ownership or control structure of corporate governance on firm performance among GLCs and non-GLCs in Malaysia found the government-owned companies perform better than non-government companies after controlling specific characteristics such as risk, corporate governance, growth and profitability. According to the study, Government Linked Investment Companies (GLICS) include Khazanah Nasional is a major shareholder in many of GLCs and therefore Government will take actions to avoid any circumstances resulting to underperformance of their investment companies. Thus, the underperformance of GLCs due to the severe impact of $1997 / 1998$ Asian financial crisis had prompted the Government to initiate a program to transform GLCs to become high performing companies and meet the expectations of stakeholders, particularly the Government.

\section{The GLCT Program}

The Government introduced and launched a spanning-10 year program known as the GLCT Program which was commenced in May 2004 and due to complete in year 2015 as an effort to improve the GLC performance. The Policy Guidelines ${ }^{6}$ on GLCT program stated:-

\footnotetext{
2 Ministry of Finance, 2007, page 92

3 Putrajaya Committee on GLCs, 2006; Ministry of Finance, 2007

${ }^{4}$ List of GLCs updated as at 13 March 2009. See; www.pcg.gov.my

5 As at 1 December 2007. See; www.treasury.gov.my/pdf/ekonomi/le/0708/bab4_0708.pdf

6 Catalysing GLC Transformation to Advance Malaysia's Development, Section II - Policy Guidelines, Version Revised: 29 July 2005.
} 
..."It is against this backdrop that the GLC Transformation Program is undertaken in the context of the GLCs' significant impact on the economy as producers, service providers, employers and capital market constituents. The urgency for transformation of GLCs is further underlined by its underperformance in terms of operations and financial indicators, at least over the last 15 years since 1990." ... (Policy Guidelines, 2005)

There are three principles underlying the GLCT include the national development foundation, performance focus and governance, and shareholder value and stakeholder management. These principles are executed through five Policy Thrusts which are structured around four key participants namely the Government, the GLCs boards, the GLCs and the GLICs.

Policy Thrust 1 is to clarify the GLCs mandate in the context of national development. Policy Thrust 2 is to upgrade the effectiveness of boards and reinforce corporate governance practices in GLCs. Policy Thrust 3 is to enhance the GLICs capabilities as professional shareholders. Policy Thrust 4 is to adopt best practices within GLCs. Policy Thrusts 1,2 and 3 are supported by Ten Iniatives to drive and enhance the GLC's performance. Policy Thrust 5 is to implement the GLCT Program.

Policy Thrust 2, which is the main focus of this research highlights that a fundamental upgrade of GLCs board effectiveness and the corporate governance of GLCs is necessary to catalyze the transformation of GLCs. The Thrust was issued with a belief that a strong correlation exists between companies with good corporate governance and long-term financial outperformance.

\section{The Green Book}

A country can adopt international corporate governance guidelines or can set its own code of best practice on characterizing an effective board. For international level, guidelines for corporate governance focusing on the role of boards have been developed by the international organizations such as the Organization for Economic Cooperation and Development (OECD) and International Corporate Governance Network (ICGN) (Bathula, 2008).

The local guidelines on enhancing board effectiveness among the Public Listed Companies (PLCS) are set out by the voluntary MCCG principles and the mandatory revamped Bursa Securities Listing Requirements. Besides the Malaysian Code of Corporate Governance (MCCG) principles, the corporate governance practices in GLCs boards must be further enhanced by the adoption and implementation of "Green Book on Enhancing Board Effectiveness" under Policy Thrusts 2 of the GLCT Program. The main objective of the Book is to upgrade GLCs board effectiveness by providing a set of comprehensive guidelines covering from compliance with the statutory, regulatory and legal responsibilities to performing beyond the stated legal forms.

The Committee expects the GLCs boards to assess their current level of board effectiveness and subsequently develop and begin to implement an actionable improvement program as at 1 January 2007 with the Chairman of the Board being responsible for leading the implementation. The Chairmen of the GLCs must ensure three main components to being an effective board are in place; (1) structuring high-performing boards, (2) ensuring effective dayto-day board operations and interactions, and (3) fulfilling their fundamental roles and responsibilities at best practice levels.

The Green Book is not only an additional instrument to the MCCG principles and Bursa Listing Requirements but also to the Malaysian Directors Academy (MINDA) program which aim 
to address board performance by equipping directors of GLCs with world class knowledge, skills and mindset to perform to a consistently high standard. The Putrajaya Committee on GLC High Performance (PCG) terms of reference describes an 'effective director' is a person who possess three requirements which are; (1) relevant knowledge, (2) skills and (3) mindsets. Apart from well equipped with practical skills, an effective director must understand the boundaries between board and management, active in problem solving with both board and key management on strategic issues while leveraging networks and managing multiple stakeholders in a proactive manner. The guidelines emphasizes on performance aspects of boards consistent with MCCG principles and Bursa Securities Listing Requirements. Excerpt from the Green Book stated:

..."Importantly, this Green Book is consistent with and complements the Malaysian Code of Corporate Governance by emphasizing the performance aspects of Boards. It is not intended to be a comprehensive restatement of best practices, but is designed to be a helpful 'stand-alone' document that deals with some key conformance aspects of Boards and their Directors. It is also intended to be a 'living document' and so will be amended and updated as needed." 7 ...

\section{Board Characteristics of the Green Book}

The board is seen as the backbone of corporate governance (Garcia-Sanchez, 2009) as their main responsibility is to provide effective governance over the company affairs. It is crucial for a listed company to have an effective board with the capabilities to align the management's interests and the shareholders' interests as the board bears overall accountability for the performance of the company. A suitable board characteristic is necessary to produce an effective board while an effective board on the other hand would likely produce positive performance by the company.

Board independence and size are among structural measures to determine board effectiveness in its monitoring function (John and Senbet, 1998) while changes in the board characteristics for example appointment of independent directors, creation of board committees and separation of the roles of chief executive officer (CEO) and the chairman contribute to board effectiveness and have been long advocated by corporate governance codes and experts (Van den Berghe and De Ridder, 1999).

Board characteristic is not the main contributor in forming an effective board. However, according to the Green Book, GLCs with proper board characteristics will likely produce an effective board that is capable to well monitor the management and to arrive to quality decision makings.

\section{Board Size}

The Green Book structuring high performance board guidelines propose that board is preferably no larger than 10 directors but can be up to 12 directors with valid reasons. Number of directors should be sufficient to ensure that the board can effectively discharge its roles and responsibilities. At the same time, the size must be contained so that the board does not become too large, which could then compromise board dynamics and the accountability of individual directors.

\footnotetext{
7 The Green Book, Enhancing Board Effectiveness, April 2006.See; www.pcg.gov.my/PDF/GREENBOOK_BINDER.pdf
} 
Empirical studies show that boards with large numbers of directors tend to be less effective as the benefits of increasing monitoring function is outweighed by such the costs of slow decision-making function (Jensen, 1993) and free-rider problems (Hermalin and Weisbach, 2003). Increasing board size would make board become less effective due to difficulties in coordinating a large board (Yermack, 1996). Jensen (1993) recommended boards to consist of seven to eight members while Lipton and Lorsch (1992) advocated board size to be eight or nine.

However, Kiel and Nicholson (2003) found larger board size effects positively on performance of firms in Australia. Adam and Mehran (2003) and Belkhir (2009) concluded larger board size is positively related to performance for regulated and complex organizations of banks and financial institutions. Findings by Bozec and Dia (2007) in Canada showed board size is positively related to firm technical efficiency when Canadian state-owned enterprises (SOEs) are exposed to market discipline. A meta-analysis study by Dalton et al. (1998) found there is a positive relationship between board size and firm performance. Cole et al. (2007) found the relationship between board size and Tobin's $Q$ is $U$-shaped, suggesting that either a very small or a very large board is optimal but this relation only arises from differences between complex and simple firms.

Proponents for smaller board size include by Barnhart and Rosenstein (1998) who proved that firms with smaller board size performed better than firms with larger board size. Similarly, Yermack (1996) reported an inverse association between board size and firm value as measured by Tobin's Q. The effect of board size on variable performance measures done by Guest (2009) found board size has a strong negative impact on profitability, Tobin's $Q$ and share returns in the UK listed firms. Cheng (2006) showed larger boards are associated with lower within-firm, overtime variability in monthly stock returns, annual accounting return on assets (ROA) and Tobin's Q. Mak and Kusnadi (2004) found there is an inverse relationship between board size and firm value of Malaysia and Singapore listed firms with the implementation of corporate governance codes in response to the 1997 Asian financial crisis.

\section{Board Independence}

The Green Book structuring high performance board guidelines is in line with the MCCG recommendations covered under Part 1 and Part 2 of the Code on board independence where there should be no more than two executive directors and at least $1 / 3$ of the board is independent to ensure fair representation from management and shareholders. The recommendation became compulsory under Bursa Malaysia Listing Requirements for all listed companies include listed GLCs.

Empirical research by Fama and Jensen (1983) stated independent directors have incentives to carry out their monitoring task and not to collude with top managers to expropriate shareholders wealth and therefore increase the board's ability in monitoring the top management. Increasing in the number of outside directors on the board increases firm performance as they can more effectively monitor managers (Adam and Mehran, 2003).

In Canada, Panasian et al. (2003) study the impact of Dey Committee guidelines recommending boards to comprise a majority of independent directors and provide evidence that adoption of this recommendation positively affect performance. Empirical study by Black et al. (2006) found the proportion of independent directors in Korean firms has positive correlation with firm performance represented by Tobin's Q while Dehaene et al. (2001) concluded there is 
a significant positive relationship between the number of external directors and return on equity (ROE) using a sample of 122 Belgian companies. A study by Lin and Xiao (2009) found that in China, there is a positive relationship between proportion of independent directors in state and non-state listed firms and their performance measured by ROA and ROE but without any significant link.

American public companies boards are more dominated by independent directors where there can be a 'supermajority independent board' with only one or two inside directors. However, companies with more independent directors have negative association with corporate performance as been found by Bhagat and Black (2001). Ramdani and Van Witteloostuijn (2009) concluded proportion of independent directors has an effect on firm performance only for firms with average performance and not for underperforming firms or those performing above par. Dalton et al. (1998) did not find a robust relationship between board independence and firm performance. Abdullah (2004) found Malaysian listed companies boards were generally dominated by independent directors but his findings suggest board independence did not show any relations with firm performance.

\section{RESEARCH METHODOLOGY}

\section{Sample Selection and Data Collection}

Study period covers three years before (2004, 2005 and 2006) and three years after (2007, 2008 and 2009) issuance of the Green Book on 1 January 2007 to observe the effect and make comparisons which consist sample of $21 \mathrm{GLCs}$ selected from $33 \mathrm{GLCs}$ which are listed and updated in PCG webpage as at 13 March 2009. GLCs from financial sector were excluded in this study because have different regulation. This study also used 21 non-GLCs of Similar/Closer Industry with Similar Size. Information on board size, number of independent directors and board remuneration are collected from the Annual Reports. Data on total assets and earnings before interest and tax (EBIT) are obtained from the Financial Statements of Annual Reports and are used to calculate the ROA. Information on number of shares outstanding and historical market share prices during periods of study are collected in the Notes to Financial Statements of the Annual Reports and Yahoo Finance Malaysia respectively to calculate for Tobin's Q. 
Measurement of Variables

Table 3.1: Summary of Variables and the Measurements

\begin{tabular}{|c|c|}
\hline Variables & Terms of measurement \\
\hline \multicolumn{2}{|l|}{ Independent Variables } \\
\hline $\begin{array}{c}\text { Board Size } \\
\text { (SIZE) }\end{array}$ & Total number of directors on board. \\
\hline $\begin{array}{l}\text { Independent Director } \\
\text { (NED) }\end{array}$ & $\begin{array}{l}\text { The percentage of total non-executive/independent directors } \\
\text { over board size. }\end{array}$ \\
\hline $\begin{array}{l}\text { Independent Directors for } \\
\text { a range of } \geq 33.33 \% \text { but }< \\
50 \%, \text { and } \geq 50 \% \\
\text { (NED3and5) }\end{array}$ & $\begin{array}{l}\text { This is a binary variable which has a value of "zero" if there is a } \\
\text { low proportion (at least } 1 / 3 \text { or } 33.33 \% \text { but less than } 50 \% \text { ), and has } \\
\text { a value of "one" if there is a high proportion (at least } 50 \% \text { ) of } \\
\text { outside directors on board. }\end{array}$ \\
\hline $\begin{array}{l}\text { Remuneration } \\
\text { (REMUN) }\end{array}$ & Total annual remunerations of directors on board. \\
\hline \multicolumn{2}{|l|}{ Dependent Variables } \\
\hline $\begin{array}{c}\text { Return on Asset } \\
\text { (ROA) } \\
\end{array}$ & $\begin{array}{l}\text { The ratio of earnings before interest and tax (EBIT) over total } \\
\text { assets. }\end{array}$ \\
\hline Tobin's Q & The ratio of market capitalization over total assets. \\
\hline \multicolumn{2}{|l|}{ Control Variable } \\
\hline $\begin{array}{c}\text { Total Assets } \\
\text { (TA) }\end{array}$ & The sum of current assets and non-current assets. \\
\hline
\end{tabular}

\section{Statistical Analysis}

To answer the first and second objective, Wilcoxon-Signed Rank test (non-parametric) is executed to compare GLCs performance before and after issuance of the Green Book. Multiple regression analysis is used to answer the final objective. Bellow are two regression models are established as follows:

$R O A=B_{0}+B_{1} S I Z E+B_{2} N E D+B_{3} R E M U N+$ Control Variable $+\varepsilon$

$T O B I N ' S Q=B_{0}+B_{1} S I Z E+B_{2} N E D+B_{3} R E M U N+$ Control Variable $+\varepsilon$

Where,

$B_{0}=$ intercept, when all other independent variables are zero

$R O A=$ is a proxy for accounting performance measure calculated as the ratio of EBIT over total assets

TOBIN'S $Q=$ is a proxy for market performance measure calculated as the ratio of market capitalization over total assets

SIZE = the total number of directors on the board

NED $\quad=$ the percentage of total independent directors over board size

REMUN = the log total annual remunerations of directors on the board 


$$
\begin{array}{lll}
\text { Control } & =\text { the log total assets of company } \\
\varepsilon & =\text { error term }
\end{array}
$$

\section{RESULT AND DISCUSSION}

\section{Descriptive Statistics}

Descriptive statistics are executed to describe and summarize the characteristics of the sample. Table 4.1 shows the descriptive results for board size, board independence, board remuneration and GLCs performance based on their corporate Annual Reports before (combination of year and after issuance of the Green Book.

\begin{tabular}{|c|c|c|c|c|c|c|}
\hline Variable & Period & Mean & Median & $\begin{array}{l}\text { Standard. } \\
\text { Deviation }\end{array}$ & Minimum & Maximum \\
\hline \multirow[b]{2}{*}{ Board Size } & $\begin{array}{c}3 \text { yrs } \\
\text { before }\end{array}$ & 8.41 & 8 & 1.399 & 6 & 12 \\
\hline & $\begin{array}{l}3 \text { yrs } \\
\text { after }\end{array}$ & 8.57 & 9 & 2.061 & 5 & 13 \\
\hline \multirow[b]{2}{*}{ NED } & $\begin{array}{c}3 \text { yrs } \\
\text { before }\end{array}$ & 44.0559 & 43 & 9.8965 & 28.57 & 78 \\
\hline & $\begin{array}{l}3 \text { yrs } \\
\text { after }\end{array}$ & 46.5548 & 45 & 7.75431 & 30 & 63 \\
\hline \multirow[b]{2}{*}{ Remuneration } & $\begin{array}{l}3 \text { yrs } \\
\text { before }\end{array}$ & 1483086 & 1269167 & 845024.2 & 286000 & 4503000 \\
\hline & $\begin{array}{l}3 \text { yrs } \\
\text { after }\end{array}$ & 2061779 & 1719000 & 1422947 & 245600 & 6995074 \\
\hline \multirow[b]{2}{*}{ ROA } & $\begin{array}{c}3 \text { yrs } \\
\text { before }\end{array}$ & 9.6141 & 8.68 & 11.49117 & -23.26 & 71.41 \\
\hline & $\begin{array}{l}3 \text { yrs } \\
\text { after }\end{array}$ & 8.2225 & 7.37 & 9.06327 & -8.46 & 53.02 \\
\hline \multirow[b]{2}{*}{ Tobin's Q } & $\begin{array}{c}3 \text { yrs } \\
\text { before }\end{array}$ & 4.3737 & 1.19 & 9.56167 & -7.29 & 58.36 \\
\hline & $\begin{array}{l}3 \text { yrs } \\
\text { after }\end{array}$ & 1.0189 & 0.73 & 1.15908 & 0.04 & 62.58 \\
\hline
\end{tabular}

Table 1: Descriptive Statistics

Referring above table 1, mean of the board size shows a small increase from 8.41 before issuance to 8.57 after issuance. Next, mean for percentage of independent directors show an increase from $44.1 \%$ before issuance to $46.6 \%$ after issuance indicating that GLCs are adding more of independent directors with the launching of Green Book. In regard with minimum board remuneration before issuance is $\mathrm{RM} 286,000$ but decrease to $\mathrm{RM} 245,600$ after issuance. The maximum board remuneration is RM4,503,000 before issuance and increase to RM6,995,074 after issuance.

Higher ROA shows an effective use of GLCs assets in serving economic interests of shareholders. The results show mean of $9.61 \%$ before issuance decrease to $8.22 \%$ after issuance. 
Finally, consistent with the results of ROA above, the mean for Tobin's Q ratio decrease from 4.37 before issuance to 1.02 after issuance assuming market's perception of GLCs performance is lower after issuance of the Green Book.

\section{GLCs Performance Before and After the Green Book}

Wilcoxon-Signed Rank test is a non-parametric measure used to determine if there is any significant difference in GLCs performance before (2004, 2005 and 2006) and after (2007, 2008 and 2009) issuance of the Green Book.

Table 2: GLCs Performance Before and After Issuance

\begin{tabular}{|l|r|r|}
\hline & $\begin{array}{c}\text { ROA 3 yrs after - ROA 3 } \\
\text { yrs before }\end{array}$ & \multicolumn{2}{|c|}{$\begin{array}{c}\text { Tobin's Q 3 yrs after - Tobin's Q 3 } \\
\text { yrs before }\end{array}$} \\
\hline Z & $-.911^{*}$ & $-2.593^{*}$ \\
Asymp. Sig. (2-tailed) & .363 & $.010^{* *}$ \\
\hline
\end{tabular}

* Based on positive ranks, ${ }^{* *}$ significant at $1 \%$.

The results for ROA is negative as Z-value score is -0.911 and $p$-value is $0.363>0.05$ while the results for Tobin's $Q$ is positive whereby Z-value score is -2.593 and $p$-value is $0.01<0.05$. Thus, it can be concluded that there is no significant difference in GLCs accounting performance before and after issuance of the Green Book while GLCs market performance measure by Tobin's $Q$ is significantly different before and after issuance of the Green Book. Shakir (2007) point out that the effectiveness of the board does not depend on how many directors sit on it, although a minimum number of directors with adequate experience and knowledge is vital to ensure tasks are carried out efficiently.

Table 3: Non-GLCs Performance Before and After Issuance

\begin{tabular}{|l|r|r|}
\hline & $\begin{array}{c}\text { ROA 3 yrs after - } \\
\text { ROA 3 yrs before }\end{array}$ & $\begin{array}{c}\text { Tobin's Q 3 yrs after - } \\
\text { Tobin's Q 3 yrs } \\
\text { before }\end{array}$ \\
\hline$Z$ & $-0.110^{*}$ & $-1.837^{*}$ \\
\hline Asymp. Sig. (2-tailed) & .913 & .066 \\
\hline * Based on positive ranks.
\end{tabular}

Table 3 presents the results of Wilcoxon-Signed Rank test on non-GLCs performance. For ROA, the Z-value score is -0.110 and $p$-value is $0.913>0.05$ while for Tobin's $Q$, Z-value score is -1.837 and $p$-value is $0.066>0.05$. Results for non-GLCs above show insignificant difference in both market and accounting performances before and after issuance of the Green Book. Thus, it can be concluded that market performance of GLCs differ significantly with the issuance of the Green Book as compare to non-GLC. This supports that to indicate that the Green Book is an effective additional instrument to strengthen the GLCs boards. 
Table 4: Regression Analysis

\begin{tabular}{|l|r|r|r|r|}
\hline & \multicolumn{2}{|c|}{ ROA } & \multicolumn{2}{c|}{ Tobin's Q } \\
\hline & \multicolumn{1}{|l|}{$\begin{array}{l}\text { Before } \\
\text { Issuance }\end{array}$} & $\begin{array}{l}\text { After } \\
\text { Issuance }\end{array}$ & $\begin{array}{l}\text { Before } \\
\text { Issuance }\end{array}$ & \multicolumn{1}{l|}{$\begin{array}{l}\text { After } \\
\text { Issuance }\end{array}$} \\
\hline R-squared & 0.276 & 0.289 & 0.4 & 0.363 \\
\hline Adjusted R-squared & 0.076 & 0.084 & 0.16 & 0.132 \\
\hline S.E. of regression & 0.013 & 0.02 & 0.102 & 0.072 \\
\hline Sum squared residual & 26.05371 & 9.0409 & 7.28858 & 9.65199 \\
\hline F-statistic & 1.196 & 1.323 & 2.759 & 2.201 \\
\hline ANOVA Prob (F-statistic) & 0.322 & 0.272 & $0.036^{*}$ & 0.08 \\
\hline
\end{tabular}

*significant at $5 \%$.

Based on Table 4 using ROA as the performance indicator, there is no significant relationship between the board characteristics and GLCs accounting performance before and after issuance. The $p$-value $=0.036<0.05$ shows there is a significant relationship between the board characteristics and GLC market performance before issuance. However, the $p$-value $=0.08$ $>0.05$ shows there is no significant relationship between the board characteristics and GLCs market performance after issuance. It can be deduced that the difference in the market performance of the GLCs is driven from the gaining confidence of shareholders towards the GLCs, led by effective GLCs boards.

\section{GLCs Performance with Different Proportion of NED}

GLCs with different proportion of independent directors are further analyzed to determine their effect on GLCs performance. Earlier it was hypothesized in $\mathrm{H} 3 \mathrm{a}$ ) that GLCs with low proportion (33.33\% to $49.99 \%$ ) or high proportion (50\% or more) of independent directors do not show significant difference in performance to each other before (2004, 2005 and 2006) and after (2007, 2008 and 2009) issuance of the Green Book. Mann-Whitney U test is executed to examine the hypothesis above using ROA and Tobin's $Q$ as performance indicators. The results are shown in Table 4.10 and 4.11 below.

Table 5: Proportion of NED and GLCs based on Rank

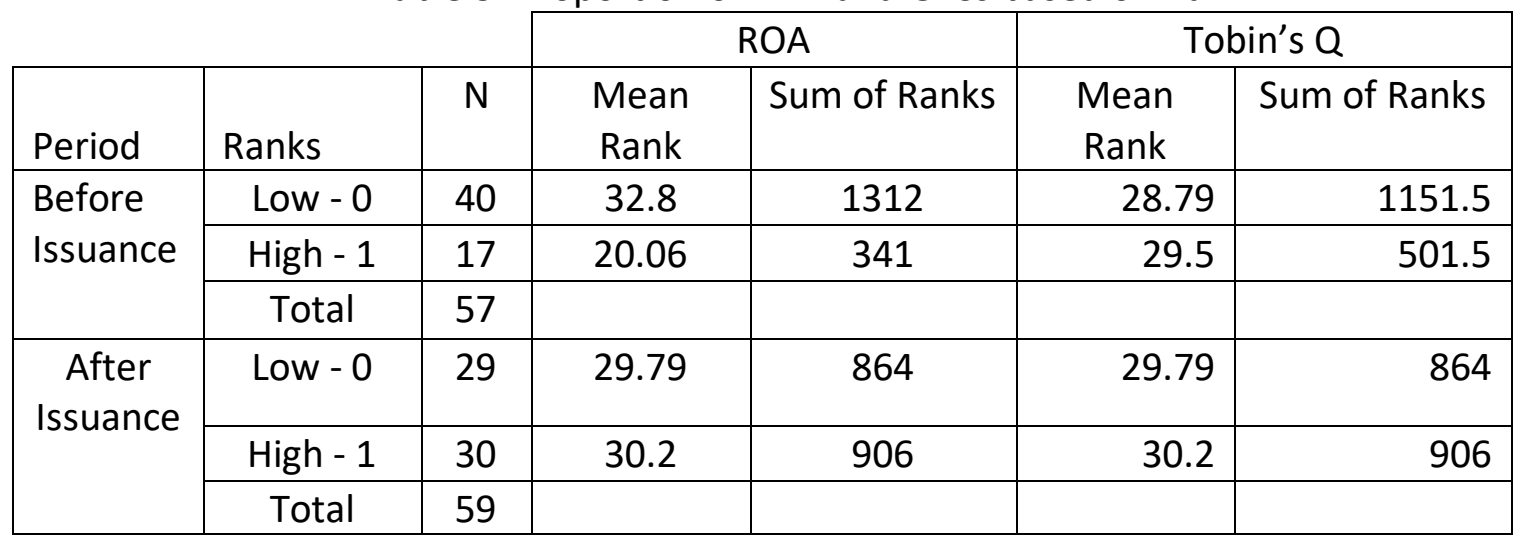


Based on the above table shows that different ranks of low proportion (33.33\% to $49.99 \%$ ) or high proportion ( $50 \%$ or more) before and after issuance. Higher mean value of ROA appears in high rank of NED after issuance. However, there is no much different mean rank of Tobin's $Q$ before and after issuance.

Table 6: Test Statistics for ROA and Tobin's Q Performance

\begin{tabular}{|c|l|c|c|}
\hline Period & Test Statistics & ROA & Tobin's Q \\
\hline \multirow{3}{*}{ Before Issuance } & Mann-Whitney U & 188 & 331.5 \\
\cline { 2 - 4 } & Wilcoxon W & 341 & 1151.5 \\
\cline { 2 - 4 } & Z & -2.651 & -0.148 \\
\cline { 2 - 4 } & Asymp. Sig. (2-tailed) & $0.008^{* *}$ & 0.882 \\
\hline \multirow{4}{*}{ After Issuance } & Mann-Whitney U & 429 & 389 \\
\cline { 2 - 4 } & Wilcoxon W & 864 & 854 \\
\cline { 2 - 4 } & Z & -0.091 & -0.698 \\
\cline { 2 - 4 } & Asymp. Sig. (2-tailed) & 0.928 & 0.485 \\
\hline
\end{tabular}

$* *$ significant at $1 \%$.

The results using ROA as performance indicator show there is a statistically significant difference in accounting performance for GLCs with different composition of independent directors before issuance of the Green Book at p-value of $0.008<0.05$. There is no significant difference in accounting performance for GLCs after the issuance. This analysis is continued on 
Table 7: Summary of Results

\begin{tabular}{|c|c|c|c|}
\hline Objectives & $\begin{array}{c}\text { Tests } \\
\text { Executed }\end{array}$ & Results & Objectives \\
\hline & & $\begin{array}{c}\text { ROA } \\
\text { (Accounting Performance) }\end{array}$ & $\begin{array}{r}\text { Tobin's Q } \\
\text { (Market Performance) }\end{array}$ \\
\hline $\begin{array}{l}\text { 1. To determine whether there is any } \\
\text { significant difference in GLCs } \\
\text { performance before and after) } \\
\text { issuance of the Green Book. }\end{array}$ & $\begin{array}{l}\text { Wilcoxon- } \\
\text { Signed Rank }\end{array}$ & $\begin{array}{l}\text { No significant difference in } \\
\text { GLCs accounting } \\
\text { performance before and } \\
\text { after issuance of the Green } \\
\text { Book. }\end{array}$ & $\begin{array}{l}\text { There is a significant difference in } \\
\text { GLCs market performance before and } \\
\text { after issuance of the Green Book. }\end{array}$ \\
\hline $\begin{array}{l}\text { 2. To investigate whether the Green } \\
\text { Book is an effective additional } \\
\text { instrument to strengthen GLCs } \\
\text { boards by comparing GLCs } \\
\text { performance with non-GLCs } \\
\text { performance before and after } \\
\text { issuance of the Green Book. }\end{array}$ & $\begin{array}{l}\text { Wilcoxon- } \\
\text { Signed Rank }\end{array}$ & \multicolumn{2}{|c|}{$\begin{array}{l}\text { No significant difference in both market and accounting performances } \\
\text { for non-GLCs before and after issuance of the Green Book as compare } \\
\text { to significant difference in GLCs market performance before and after } \\
\text { issuance of the Green Book. }\end{array}$} \\
\hline $\begin{array}{l}\text { 3. To examine whether board } \\
\text { characteristics (size, independence } \\
\text { and remuneration) has any } \\
\text { significant relationship to GLCs } \\
\text { performance before and after } \\
\text { issuance of the Green Book. }\end{array}$ & $\begin{array}{l}\text { Multiple } \\
\text { regression }\end{array}$ & $\begin{array}{l}\frac{\text { After issuance }}{\text { No significant relationship. }} \\
\text { Before issuance } \\
\text { Has significant relationship. }\end{array}$ & $\begin{array}{l}\text { After issuance } \\
\text { No significant relationship. } \\
\text { Before issuance } \\
\text { No significant relationship. }\end{array}$ \\
\hline $\begin{array}{l}\text { 3.a To determine whether GLCs with } \\
\text { low proportion ( } 33.33 \% \text { to } 49.99 \% \text { ) } \\
\text { or high proportion ( } 50 \% \text { and above) } \\
\text { of independent directors would } \\
\text { perform significantly different to } \\
\text { each other before and after } \\
\text { issuance of the Green Book }\end{array}$ & $\begin{array}{l}\text { Mann- } \\
\text { Whitney U } \\
\text { Test }\end{array}$ & $\begin{array}{l}\text { GLCs with low and high } \\
\text { proportion of independent } \\
\text { directors sits on board show } \\
\text { significant difference to each } \\
\text { other only in accounting } \\
\text { performance before but not } \\
\text { after issuance of the Green } \\
\text { Book }\end{array}$ & $\begin{array}{l}\text { GLCs with low and high proportion of } \\
\text { independent directors sits on board } \\
\text { show no significant difference in } \\
\text { market performances before and } \\
\text { after issuance of the Green Book }\end{array}$ \\
\hline
\end{tabular}


Tobin's $Q$ as performance indicator and the results are presented as below. Using Tobin's $Q$ as performance indicator, the results show there is no significant difference in market performance for GLCs with low proportion and high proportion of independent directors before and after issuance of the Green Book. It was expected that compliance to board characteristic of the Green Book would strengthen the GLCs boards and ultimately improve GLCs performance. However, the negative results indicate the otherwise. This means that compliance to the board characteristics of the Green Book does not influence the accounting or market performance of the GLCs.

\section{CONCLUSION AND RECOMMENDATION FUTURE RESEACH}

Under the GLCT Program the Green Book was issued to enhance board effectiveness. This study aims to examine whether board characteristics in compliance to the Green Book policy guidelines has any effect on GLCs performance. The board characteristics variables here are board size, board independence and board remuneration. Findings for suggest that there is an improvement in GLCs market performance but not in accounting performance with the issuance of the Green Book. The Green Book is an effective additional best practice instrument to strengthen the GLCs boards. However, results show compliance with board size, board independence and board remuneration of the Green Book do not affect GLCs performance after controlling with GLCs' size. Results also suggest that having low or high proportion of independent directors in GLCs boards do not influence GLCs performance. Overall, the results suggest the Green Book is an effective instrument to increase board effectiveness in its monitoring function. However, compliance to the board characteristics of board size, board independence and board remuneration of the Green Book is insufficient to give a huge impact on GLCs performance. Therefore, corporate governance factor of the Green Book has little influence and do not contribute much on GLCs performance.

This study can be extended to examining most of the board characteristics variables of the Green Book which are size, independence, remuneration, experience and directorship on GLCs performance. The Book requires GLCs boards to ensure three main components of an effective board are in place to truly raise their effectiveness. These components are; (1) structuring a high-performing board, (2) ensuring effective day-to-day board operations and interactions and (3) fulfilling the board's fundamental roles and responsibilities to best practice levels. As this study limits its scope to the first component, therefore, future research can be extended to examine the other three components altogether and their effect on GLCs performance. Also, future research should extend the years of study until the GLCT program complete in year 2015 and GLCs performance before and after issuance of the Green Book should then be compared to see the real effect of the Green Book on strengthening GLCs boards.

\section{ACKNOWLEDMENT}

This paper is part of Master of Accountancy Dissertation Universiti Teknologi MARA (UiTM).

\section{REFERENCES}

Abdullah, S.N. (2004). Board Composition, CEO Duality and Performance among Malaysian Listed Companies. Corporate Governance, 4 (4): 47-61. 
INTERNATIONAL JOURNAL OF ACADEMIC RESEARCH IN BUSINESS AND SOCIAL SCIENCES

Vol. 9, No. 1, Jan, 2019, E-ISSN: 2222-6990 @ 2019 HRMARS

Adam, R. B., and Mehran, H. (2003). Is Corporate Governance Different for Bank Holding Companies? Economic Policy Review - Federal Reserve Bank of New York, 9 (1): 123-142.

Ahmad, R., Aliahmed, H.J. and Ab Razak, N.H., (2008). Government Ownership and Performance: An Analysis of Listed Companies in Malaysia. Available at SSRN: http://ssrn.com/abstract=1252072 downloaded on 2 March 2010 .

Barnhart, S. W. and Roseinstein, S. (1998). Board Composition, Managerial Ownership, and Firm Performance: An Empirical Analysis. The Financial Review, 33: 1-16.

Bathula, H. (2008). Board Characteristics and Firm Performance: Evidence from New Zealand, PhD Thesis, Auckland University of Technology, New Zealand.

Bhagat, S. and Black, B.S., (2001) The Non-Correlation between Board Independence and Long-Term Firm Performance. Journal of Corporation Law, 27: 231-273.

Bozec, R. and Dia, M. (2007). Board Structure and Firm Technical Efficiency: Evidence from Canadian State-Owned Enterprises. European Journal of Operational Research, 177 (3): 1734-1750.

Cheng, S. (2008). Board Size and the Variability of Corporate Performance. Journal of Financial Economics, 87 (1): 157-176

Cole, J.L., Daniel, N.D. and Naveen, L. (2007). Boards: Does One Size Fit All?. Journal of Financial Economics, 87 (2): 329-356

Fama, E. and Jensen, M.C. (1983). Separation of Ownership and Control. Journal of Law and Economics, 26: 301-326.

Garcia-Sanchez, I.M. (2009). The Effectiveness of Corporate Governance: Board Structure and Business Technical Efficiency in Spain. Central European Journal of Operations Research, Physica Verlag, An Imprint of Springer-Verlag GmbH.

Guest. P.M. (2008). The Determinants of Board Size and Composition: Evidence from the UK. Journal of Corporate Finance, 14(1): 51-72

Hermalin, B and Weisbach, M. (2003). Boards of Directors as an Endogenously Determined Institution: A Survey of the Economic Literature, Federal Reserve Bank of New York Policy Review, 9(1): 7-26.

Jensen, M. (1993). The Modern Industrial Revolution, Exit and the Failure of Internal Control Systems. Journal of Finance, 48(3): 831-880.

Kiel, G.C. and Nicholson, G.J. (2003). Board composition and corporate performance: How the Australian experience informs contrasting theories of corporate governance, Corporate Governance, 11(3): 189-205.

Lin, Y. and Xiao, H. (2009). Research on the Correlation between Characteristics of Board System and Firm Performance in China: The Comparison between State and Non-State Listed Companies. Asian Social Science, 3(5): 93-100.

Mak, Y.T. and Kusnadi, Y. (2004). Size really matters: Further Evidence on the Negative Relationship between Board Size and Firm Value, Pacific-Basin Finance Journal, 13 (3): 301-318.

Ministry of Finance (2007). Economic Report 2007/2008, Percetakan Nasional Malaysia Berhad, Kuala Lumpur, Malaysia.

Panasian, C., Prevost, A.K. and Bhabra, H.S., (2003). Board Composition and Firm Performance: The Case of the Dey Report and Publicly Listed Canadian Firms. Working Paper, Department of Finance, Montreal University. 
Ramdani, D. and Van Witteloostuijn, A. (2009). Board Independence, CEO Duality and Firm Performance: A Quantile Regression Analysis for Indonesia, Malaysia, South Korea and Thailand. Research Paper, Faculty of Applied Economics, University of Antwerp.

Shakir, R. (2008). "Board size, executive directors and property firm performance in Malaysia." Pacific Rim Property Research Journal, 14(1): 66-80.

Van Den Berghe, L. and De Ridder, L. (1999). International Standardisation of Good Corporate Governance Best Practice for the Board of Directors, Kluwer Academic Publishers, Boston, MA.

Yermack, D. (1996). Higher Market Valuation of Companies with a Small Board of Directors. Journal of Financial Economics, 40 (2): 185-211. 